\title{
Box-Behnken Design Approach for Optimizing Removal of Copper from Wastewater Using a Novel and Green Adsorbent
}

\author{
Muharrem Ince ${ }^{a *}$ and Olcay Kaplan Ince ${ }^{b}$ \\ a Munzur University, Faculty of Engineering, Department of Chemical Engineering, \\ 62000 Tunceli, Turkey \\ b Munzur University, Faculty of Engineering, Department of Food Engineering, \\ 62000 Tunceli, Turkey
}

\begin{abstract}
The aim of the present research was to apply the Box-Behnken experimental design and response surface methodology for modeling of copper $\left(\mathrm{Cu}^{2+}\right)$ ions from an industrial wastewater and leachate pretreated astragalus herbal plant. A three factor, three level Box-Behnken experimental design combined with response surface modeling (RSM) and quadratic programming (QP) was employed for maximizing $\mathrm{Cu}(\mathrm{II})$ removal from aqueous solution based on 17 different experimental data obtained in a batch experimental study. Three independent variables ( $\mathrm{pH}$ ranging from 2.0 to 8.0, contact time from 10 to 180 minutes, and adsorbent amount from 0.1 to $1 \mathrm{~g}$ ) were studied. The significance of the independent variables and their interactions were tested by means of the analysis of variance (ANOVA) with $95 \%$ confidence limits. The
\end{abstract}

standardized effects of the independent variables and their interactions on the dependent variable were also investigated by preparing a Pareto chart. The optimum values of the selected variables were obtained by solving the quadratic regression model as well as by analyzing the response surface contour plots. Using the experimental conditions of $\mathrm{pH}=5.0$, contact time $=92.5$ minutes, adsorbent dosage $=0.25 \mathrm{~g}$, the recovery efficiency of $\mathrm{Cu}(\mathrm{II})$ was found to be $100 \%$.

Copper-free and copperloaded astragalus was analyzed using fourier transform infrared spectrometry (FTIR) which evidenced the functional groups involved in copper uptake. Adsorption equilibrium for copper was described by using the Freundlich and Langmiur adsorption isotherms. This adsorbent was applied to different industrial wastewater and leachate samples for copper removal.

\section{INTRODUCTION}

The increase in industrial activity has led to environmental contamination from various harmful components due to the lack of strict control of waste quality (1). As is well known, copper is one of the most common and important pollutants in the environment, especially in water and industrial wastewater, and since it is non-biodegradable, its toxic effects have become a pub-

\footnotetext{
*Corresponding autbor.

E-mail: mubarremince@munzur.edu.tr

Tel: +904282131794

Fax: +904282131624
}

lic health concern. The most toxic or cancinogenic metals are mercury $(\mathrm{Hg})$, cadmium $(\mathrm{Cd})$, lead $(\mathrm{Pb})$, and copper $(\mathrm{Cu})(2)$. Heavy metals pollution, especially from copper, comes from different natural activities and industrial effluents. If these metals enter the ecosystem, they will be easily adsorbed by marine animals and directly enter the human food chain causing serious health problems in the liver, brain, dysfunction of the kidney, the reproductive and the central nervous systems $(3,4)$. The toxicity of these metals accumulates in living tissues with consequent biomagnification in the food chain $(5,6)$.
Thus, it becomes vital to reduce and control the permissible heavy metals levels in wastewaters $(1,7)$. Currently, the removal of toxic metal contaminants from various aqueous waste systems is one of the most important environmental issues. In order to remove heavy metals from contaminated water, especially industrial effluents, a variety of physicochemical methods including chemical precipitation (8), ion exchange (9), nanofiltration, low energy reverse osmosis (10), and ultra filtration have been proposed. Reverse osmosis, although very effective, is a very costly process since it requires frequent membrane replacement. On the other hand, when the pollutants are at trace levels, chemical precipitation is not a suitable method. While ion exchange is expensive and sophisticated, solvent extraction or electrolytic processes are also available but they are not considered to be costeffective methods (11). Hence, most of these processes are not widely acceptable because of disadvantages such as difficulty in the disposal of sludge, low efficiency, and inapplicability to a wide range of pollutants (12-15).

In recent years, the adsorption technology used for the purification of water has received increasing attention because it is effective, simple, and economical (16-20). To obtain cheaper and effective adsorbents, various materials such as lignocellulosics have been investigated. For this purpose, cheaper and abundantly available adsorbents for the determination of metals in agricultural waste have been used and studied such as tea waste, 
peanut hull, banana peel, hazelnut shells, saw dusts, pine bark, coconut husk, peanut skins, rice hulls, and almond shells in addition to different agricultural products (21-25).

For metal removal in aqueous systems, ion exchange, reverse osmosis, chemical precipitation, and electrolysis are frequently employed. For effluent treatment, many strategies and techniques have been investigated and reported (26-28). Due to the critical importance of adsorption processes, the development of low cost, effective, and eco-friendly methods is very important and necessary (29-32). There are two different classes in terms of these materials: natural materials include natural zeolites, coal, coir, rice husk, clay, and biosorbents such as fungi, algae, and bacteria $(33,34)$. The astragalus plant can be considered as an effective, natural, and environmentally friendly material for its application in effluent treatment. To our knowledge, this material, in its natural form, has never been applied for this purpose.

In this study, the feasibility of astragalus as an economical and abundantly available adsorbent for the removal of copper from wastewater samples is used in a batch system. For this purpose, the BoxBehnken model experimental design in response surface modeling (RSM) was found to be a beneficial tool to optimize the experimental conditions and to evaluate the multiple anlaytical factors and their interactions. RSM is a combination of mathematical and statistical techniques used for developing, improving, and optimizing the processes and to evaluate the relative significance of several parameters in the presence of complex interactions. Since RSM provides a mathematical model with the advantages of achieving higher percentage yield, reducing process variability, closer confirmation of output response to nominal target achievement, and less treatment time with minimum cost. At the same time to understand the adsorption mechanism, the evidence for physicochemical characteristics of astragalus obtained from FTIR analysis was investigated. The optimal experimental conditions were applied to investigate the effects of the parameters and their interactions on copper removal by adsorption. In addition, the adsorption isotherms (Freundlich and Langmuir models) were determined using these conditions. In view of these important characteristics, the aim of this work was to establish astragalus as an alternative and effective biomaterial for removing copper ions from various wastewater samples. Before and after treatment, copper concentration was determined by using flame atomic absorption spectrometry (FAAS).

\section{EXPERIMENTAL}

\section{Reagents}

Copper nitrate, sodium hydroxide, hydrochloric acid, sodium citrate monohydrate, sodium dihydrogen phosphate, sodium tetraborate and nitric acid were obtained from Merck (Darmstadt, Germany). All chemicals used were of analytical grade.

\section{Preparation of Standard Solutions}

A stock solution of $1000 \mathrm{mg} \mathrm{L}^{-1}$ $\mathrm{Cu}(\mathrm{II})$ was prepared by dissolving an accurate quantity of $\mathrm{Cu}\left(\mathrm{NO}_{3}\right)_{2}$ in ultrapure water. Other concentrations of $1 \mathrm{mg} \mathrm{L}^{-1}$ to $200 \mathrm{mg} \mathrm{L}^{-1}$ were prepared using the stock solutions by dilution.

\section{Preparation of Adsorbent}

The astragalus plant samples were collected at Turusmek (Aktuluk), a local area in Tunceli, Turkey. They were washed with tap and ultrapure water to remove the dirt, then oven-dried at $60{ }^{\circ} \mathrm{C}$ until con- stant weight, then peeled. After drying, the astragalus samples were ground in a blender, sieved to particles of $<120$ mesh, and stored at room temperature in polyethylene bags until use.

\section{Box-Behnken Experimental Design and Optimization by RSM}

The optimum conditions for maximizing the adsorption of $\mathrm{Cu}(\mathrm{II})$ by astragalus were determined by means of a three-factor, three-level Box-Behnken experimental design combined with response surface modeling and quadratic programming. According to single-factor experiments, a BoxBehnken design was used to determine three independent variables: $\mathrm{pH}\left(\mathrm{X}_{1}\right)$, contact time $\left(\mathrm{X}_{2}\right)$, and adsorbent amount $\left(\mathrm{X}_{3}\right)$ on adsorption of copper onto astragalus (Y). In order to reduce unexplained variability effects on the observed response, randomized experimental order was carried out. Seventeen experimental points including replications of the central points experimental design were used. Table I lists the different parameters such as variable conditions, run order, experimental values, and predicted values. A final equation was obtained from RSM in terms of actual factors:

$$
\begin{aligned}
& \mathrm{Y}=-2.82+1.28816 \mathrm{X}_{1}+0.015 \mathrm{X}_{2} \\
& +3.13488 \mathrm{X}_{3}-7.42857 \mathrm{E}-004 \mathrm{X}_{1} \mathrm{X}_{2} \\
& -0.16667 \mathrm{X}_{1} \mathrm{X}_{3}-1.33333 \mathrm{E}-003 \mathrm{X}_{2} \mathrm{X}_{3} \\
& -0.12003 \mathrm{X}_{1}^{2}-5.26041 \mathrm{E}-005 \mathrm{X}_{2}^{2} \\
& -1.81605 \mathrm{X}_{3}^{2}
\end{aligned}
$$

After data analysis by ANOVA in order to determine the lack of fit, other parameters were evaluated including the effects of quadratic, linear, and interaction variables for copper adsorption on astragalus. RSM and data analyses were carried out with Design Expert software program (Design Expert Version 10, Stat-Ease, USA).

All adsorption experiments were performed in Erlenmeyer flasks 
containing $\mathrm{Cu}(\mathrm{II})$ synthetic solutions and adsorbents at $<120$ mesh adsorbent particle size were added to the solutions. The effect of $\mathrm{pH}$ (2-8), contact time (10 to $180 \mathrm{~min}$ utes) and adsorbent mass (0.1-1 g) were studied at room temperature. The $\mathrm{pH}$ was adjusted using sodium hydroxide and hydrochloric acid. A model Duo S213 digital pH meter (Mettler Toledo, Switzerland) was used for $\mathrm{pH}$ measurements. The adsorbent was separated from the samples by filtering, and the filtrate was analyzed using a PerkinElmer ${ }^{\circledR}$ AAnalyst $^{\text {TM }} 800$ FAAS (PerkinElmer, Inc., Shelton, CT, USA). The instrumental operating conditions are listed in Table II. Three independent replicates were prepared and the average results are presented.

\section{Characterization of Adsorbent}

FTIR spectra of the pretreated astragalus were compared with the FTIR spectra of the astralagus spiked with copper. The spectra were recorded in the frequency range of $4000-500 \mathrm{~cm}^{-1}$ using the Thermo Nicolet iS10 FTIR spectrophotometer (Thermo Scientific, USA). The instrumental operating conditions are listed in Table III. Attenuated Total Reflectance (ATR, diamond crystal) was used for sample analysis.

\section{RESULTS AND DISCUSSION}

\section{Second-order Polynomial Model}

RSM with a Box-Behnken design and ANOVA was used for copper adsorption on astragalus and the conditions are shown in Table I and Table IV, respectively. The Model F-value of 142.17 implies that the model is significant. There is only a $0.01 \%$ chance that a F-value this large could occur due to noise. Values of "Prob $>F^{2}$ less than 0.0500 indicate that the model terms are statistically significant.

TABLE I

Box-Behnken Design and Observed Responses of Cu Levels on Astragalus ( $\mathrm{mg} \mathrm{g}^{-1}$ )

\begin{tabular}{ccrrcc}
\hline Run & $\mathrm{pH}$ & $\begin{array}{c}\text { Contact } \\
\text { Time }\end{array}$ & $\begin{array}{c}\text { Adsorbent } \\
\text { Amount }\end{array}$ & \multicolumn{2}{c}{ Copper $\left(\mathrm{q}_{\mathrm{e}}, \mathrm{mg} \mathrm{g}^{-1}\right)$} \\
\hline & $\mathrm{X}_{1}$ & $\mathrm{X}_{2}(\mathrm{~min})$ & $\mathrm{X}_{3}(\mathrm{~g})$ & $\begin{array}{c}\text { Experimental } \\
\text { Values }\end{array}$ & $\begin{array}{c}\text { Predicted } \\
\text { Values }\end{array}$ \\
\hline 1 & 2 & 5 & 0.55 & 0.33 & 0.33 \\
2 & 5 & 180 & 1 & 1.22 & 1.27 \\
3 & 5 & 180 & 0.1 & 1.28 & 1.22 \\
4 & 2 & 180 & 0.55 & 0.94 & 0.94 \\
5 & 5 & 5 & 0.1 & 0.95 & 0.90 \\
6 & 8 & 92.5 & 0.1 & 0.32 & 0.37 \\
7 & 8 & 180 & 0.55 & 0.13 & 0.12 \\
8 & 5 & 92.5 & 0.55 & 1.82 & 1.89 \\
9 & 8 & 5 & 0.55 & 0.30 & 0.29 \\
10 & 2 & 92.5 & 1 & 1.10 & 0.98 \\
11 & 5 & 5 & 1 & 1.10 & 1.20 \\
12 & 5 & 92.5 & 0.55 & 1.98 & 1.91 \\
13 & 8 & 92.5 & 1 & 0.15 & 0.12 \\
14 & 5 & 92.5 & 0.55 & 1.92 & 1.91 \\
15 & 2 & 92.5 & 0.1 & 0.32 & 0.31 \\
16 & 5 & 92.5 & 0.55 & 1.90 & 1.91 \\
17 & 5 & 92.5 & 0.55 & 1.92 & 1.91 \\
\hline
\end{tabular}


The results expressed by using the statistical model were adequate in order to predict the copper levels and were fitted to a second-order polynomial equation. In this case, while $\mathrm{X}_{1}$ is highly significant $(\mathrm{P}<0.01), \mathrm{X}_{2}, \mathrm{X}_{3}, \mathrm{X}_{1} \mathrm{X}_{2}, \mathrm{X}_{1} \mathrm{X}_{3}, \mathrm{X}_{1}^{2}$, $\mathrm{X}_{2}{ }^{2}, \mathrm{X}_{3}{ }^{2}$ are significant model terms in terms of copper adsorption on astragalus. The quadratic and linear coefficients affecting the factors on the response of copper adsorption on astragalus follow the order: $\mathrm{pH}$ $>$ contact time $>$ adsorbent amount.

\section{RSM Analysis}

Two-dimensional (2D) contour plots and three-dimensional (3D) response surface graphs were made because they are useful in determining maximum, minimum, and middle response points. With contour plots, the levels of the variables can be determined and also con- tribute to a desired response. In addition, the variable levels are plotted in a curve with equal response. Because of these reasons, contour plots are easier to interpret. Figure 1 shows the effect of $\mathrm{pH}$ and contact time on copper in astragalus. The adsorbed copper amount increased with an increase in $\mathrm{pH}$ until it reaches a plateau at 5, indicating that there are further improvements for copper levels. At the same time, contact time has important effects on copper adsorption on the adsorbent. The effects of $\mathrm{pH}$ and adsorbent amount on copper adsorption are shown in Figure 2. The interaction of these two variables had a significant effect on the adsorption process including from the quadratic variables ( $\mathrm{pH}, \mathrm{P}<0.01$; contact time, $\mathrm{P}<0.05)$. As a result, the impact of $\mathrm{pH}$ on the copper adsorption level

TABLE IV

Analysis of Variance (ANOVA) for the Quadratic Polynomial Mode

\begin{tabular}{|c|c|c|c|c|c|c|}
\hline Source & $\begin{array}{l}\text { Sum of } \\
\text { Squares }\end{array}$ & df & $\begin{array}{l}\text { Mean } \\
\text { Square }\end{array}$ & $\begin{array}{c}\mathrm{F} \\
\text { Value }\end{array}$ & $\begin{array}{l}\text { p-value* } \\
\text { Prob > F }\end{array}$ & \\
\hline Model & 7.56 & 9 & 0.84 & 142.17 & $<0.0001$ & significant \\
\hline $\mathrm{X}_{1}-\mathrm{pH}$ & 0.38 & 1 & 0.38 & 64.06 & $<0.0001$ & \\
\hline $\begin{array}{l}\mathrm{X}_{2} \text {-Contact } \\
\text { time }\end{array}$ & 0.099 & 1 & 0.099 & 16.76 & 0.0046 & \\
\hline $\begin{array}{l}\mathrm{X}_{3} \text {-Adsorbent } \\
\text { amount }\end{array}$ & 0.053 & 1 & 0.053 & 8.94 & 0.0202 & \\
\hline $\mathrm{X}_{1} \mathrm{X}_{2}$ & 0.15 & 1 & 0.15 & 25.75 & 0.0014 & \\
\hline $\mathrm{X}_{1} \mathrm{X}_{3}$ & 0.20 & 1 & 0.20 & 34.28 & 0.0006 & \\
\hline $\mathrm{X}_{2} \mathrm{X}_{3}$ & 0.011 & 1 & 0.011 & 1.87 & 0.2142 & \\
\hline $\mathrm{X}_{1}^{2}$ & 4.91 & 1 & 4.91 & 831.68 & $<0.0001$ & \\
\hline $\mathrm{X}_{2}^{2}$ & 0.68 & 1 & 0.68 & 115.61 & $<0.0001$ & \\
\hline $\mathrm{X}_{3}^{2}$ & 0.57 & 1 & 0.57 & 96.39 & $<0.0001$ & \\
\hline Residual & 0.041 & 7 & $5.908 \mathrm{E}-003$ & & & \\
\hline Lack of Fit & 0.028 & 3 & $9.358 \mathrm{E}-003$ & 2.82 & 0.1712 & $\begin{array}{l}\text { not signi- } \\
\text { ficant }\end{array}$ \\
\hline Pure Error & 0.013 & 4 & $3.320 \mathrm{E}-003$ & & & \\
\hline Cor Total & 7.60 & 16 & & & & \\
\hline R-Squared & 0.9946 & & & & & \\
\hline Adj R-Squared & 0.9876 & & & & & \\
\hline Pred R-Squared & 0.9382 & & & & & \\
\hline Adeq Precision & 30.691 & & & & & \\
\hline
\end{tabular}

${ }^{*} \mathrm{P}<0.01$ highly significant; $0.01<\mathrm{P}<0.05$ significant; $\mathrm{P}>0.05$ not significant.

\section{Atomic Apectroscopy 1 Vol. 38(6), Nov./Dec. 2017}

was more significant than of contact time. The effects of contact time and amount of adsorbent on copper adsorption onto astragalus are shown in Figure 3. The adsorbed copper amount increased with an increase in contact time until it reached a plateau at 92.5 minutes, indicating that there was no further improvement in the adsorbed copper level.

\section{Confirmation Experiments}

To support the optimized data given by numerical modeling under optimized conditions, experiments were conducted with the parameters as suggested by the model $(\mathrm{pH}$ 5.0 , adsorbent dose $0.50 \mathrm{~g} / 100 \mathrm{~mL}$, contact time 92.5 minutes, and stirring speed $150 \mathrm{rpm}$, temperature $25 \pm 1^{\circ} \mathrm{C}$ ) and the percent removal was found to be $100 \%$ (Table V). The effect of $\mathrm{pH}, \mathrm{Cu}$ (II) concentration, and adsorbent dose were also studied to verify the results.

There are many studies and different results were reported for adsorbents. Yao et al. (36) used a batch experiment system for biosorption of $\mathrm{Cu}$ (II) onto food waste adsorbent. The equilibrium data agreed well with the two isotherm models of Redlich-Peterson and Langmuir. The capacity of chestnut shell adsorption was calculated as $12.56 \mathrm{mg} \mathrm{g}^{-1}$ at room temperature with a $\mathrm{pH}$ ranging from 4-6. Jiang et al. (11) studied kaolinite clay adsorption of $\mathrm{Ni}$ (II) and reported that it increased with an increase in $\mathrm{pH}$ from 2.0 to 8.0. In another study (37), tea waste was used as the adsorbent and the maximum adsorption of $\mathrm{Ni}(\mathrm{II})$ ions was obtained at $\mathrm{pH}$ 4.0.

Zuorro and Lavecchia (38) used black and green tea leaves as the adsorbent for $\mathrm{Pb}$ removal from aqueous solution. They set the temperature at 25 or $40{ }^{\circ} \mathrm{C}$ and the contact time to 2 hours. Under the optimum experimental conditions, they also compared the results 


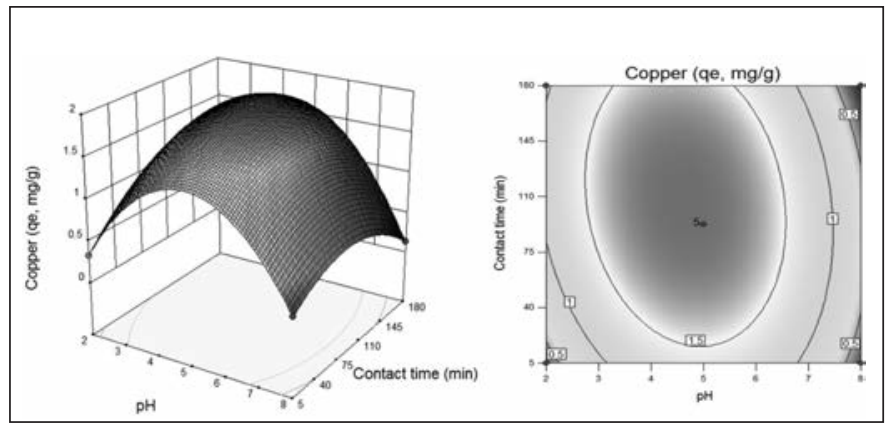

Fig. 1. Response surface and contour plot for copper sorption on astragalus as $\mathrm{pH}$ and contact time.

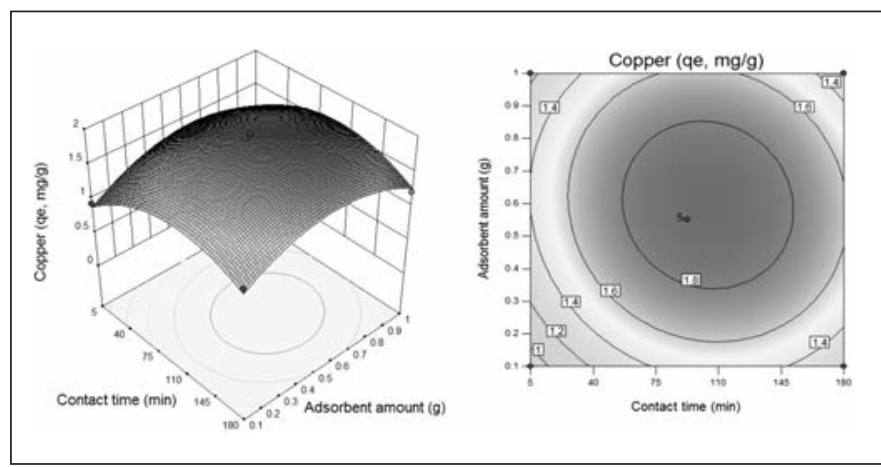

Fig. 3. Response surface and contour plot for copper sorption on astragalus as adsorbent amount and contact time.

using tea leaves and coffee grounds for the removal of lead and found that the efficiency was quite similar for both. The average adsorption capacities were $10.81 \pm 0.42 \mathrm{mg} \mathrm{g}^{-1}$ (at $40^{\circ} \mathrm{C}$ ) and $10.99 \pm 0.11 \mathrm{mg} \mathrm{g}^{-1}$ (at $25^{\circ} \mathrm{C}$ ), respectively. Ince (22) discusses the influence of contact time (10 to 180 minutes) on the adsorption of $\mathrm{Ni}(\mathrm{II})$ on low-cost and natural adsorbents such as tea waste and egg shell. The final and best contact time in that study was fixed at 45 minutes for both adsorbents (22).

Ince et al. (23) also used a batch experimental system for the removal of the heavy metals $\mathrm{Ni}(\mathrm{II})$, $\mathrm{Pb}(\mathrm{II})$, and $\mathrm{Cd}(\mathrm{II})$ with banana peel. After investigating the effects of various parameters, the maximum adsorbent amount was $0.1 \mathrm{~g}$ for $\mathrm{Pb}$, and $0.25 \mathrm{~g}$ for both $\mathrm{Cd}$ and $\mathrm{Ni}$.

In another study (24) that performed in an aqueous system, the
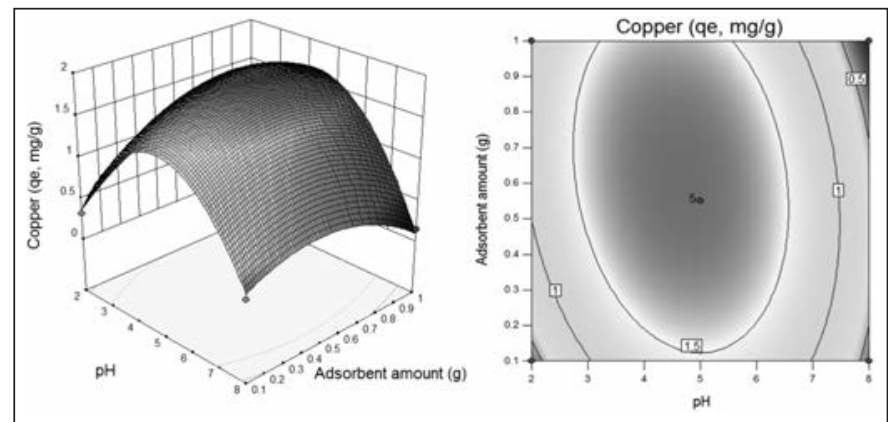

Fig. 2. Response surface and contour plot for copper sorption on astragalus as adsorbent amount and $\mathrm{pH}$.

TABLE V

Removal of Cu(II) Using Astragalus For Different Wastewater Samples

\begin{tabular}{lrrr}
\hline Sample & \multicolumn{3}{c}{$\mathrm{Cu}(\mathrm{II})\left(\mathrm{mg} \mathrm{L}^{-1}\right)$} \\
& \multicolumn{1}{c}{$\mathrm{SA}$} & \multicolumn{1}{c}{ Found } & \% Removal \\
\hline Industrial Wastewater 1 & 0.0 & $12.7 \pm 0.3$ & 100.0 \\
& 10 & $22.4 \pm 0.4$ & 98.6 \\
Industrial Wastewater 2 & 0.0 & $9.8 \pm 0.2$ & 100.0 \\
& 10 & $19.8 \pm 0.2$ & 100.0 \\
Industrial Wastewater 3 & 0.0 & $15.1 \pm 0.2$ & 100.0 \\
& 10 & $24.8 \pm 0.3$ & 98.8 \\
Leachate 1 & 0.0 & $5.9 \pm 0.2$ & 100.0 \\
Leachate 2 & 10 & $15.3 \pm 0.3$ & 96.2 \\
& 0.0 & $7.5 \pm 0.0 .2$ & 100.0 \\
Leachate 3 & 10 & $17.2 \pm 0.3$ & 98.3 \\
SRMs & 0.0 & $6.8 \pm 0.1$ & 100.0 \\
& 10 & $16.6 \pm 0.2$ & 98.8 \\
& 20.0 & $20.0 \pm 0.2$ & 99.0 \\
\hline
\end{tabular}

adsorbent hydroxyapatite was used for the removal of cadmium. The design experimental methodology and response surface methodology (RSM) was used to optimize some parameters such as $\mathrm{pH}$ and adsorbent dosage. RSM indicated that the optimum adsorbent dosage of hydroxyapatite was $0.57 \mathrm{~g}$ for the adsorption of Cd(II).

\section{Calculation of Adsorbed Cu Amount on Adsorbent}

The amount of metal adsorption was calculated using Equation 1.

$$
\mathrm{q}_{\mathrm{e}}=\left(\left(\mathrm{C}_{0}-\mathrm{C}_{\mathrm{e}}\right) \times \mathrm{V}\right) / \mathrm{m} \quad \text { Eq. (1) }
$$

where $\mathrm{q}_{\mathrm{e}}$ represents the adsorbed $\mathrm{Cu}(\mathrm{II})$ amount by the natural adsorbents $\left(\mathrm{mg} \mathrm{g}^{-1}\right) ; \mathrm{C}_{0}=$ metal concentrations in the solution before adsorption $\left(\mathrm{mg} \mathrm{L}^{-1}\right) ; \mathrm{C}_{\mathrm{e}}=$ metal concentrations in the solution after adsorption $\left(\mathrm{mg} \mathrm{L}^{-1}\right) ; \mathrm{V}=$ solution volume $(\mathrm{L}) ; \mathrm{m}=$ used adsorbent mass (g).

The natural adsorbent astralagus was used for copper adsorption and the results were calculated under optimum conditions. The $\mathrm{q}_{\mathrm{e}}$ was calculated as $1.98 \mathrm{mg} \mathrm{g}^{-1}$. According to the obtained results, astragalus is an excellent adsorbent for copper removal in wastewater samples.

\section{Adsorption Isotherms}

The isotherms of adsorption show the data calculated at the equilibrium point of the adsorbent and are represented as positive, 
smooth, and concave. The amount of toxic metal increased with the equilibrium concentration of copper in the solutions. Because of the shape of the isotherms, the data of adsorption were calculated according to the Langmuir and Freundlich equations.

\section{Langmuir Model}

The Langmuir model states that uptake occurs on a homogenous surface by monolayer adsorption with constant heat of adsorption for all sites and without interaction between adsorbed molecules (39).

The Langmuir model is given in Equation 2.

$$
q_{e}=\frac{X m b C_{e}}{1+b C_{e}}
$$

where $C_{e}$ is the solution metal ion concentration $\left(\mathrm{mg} \mathrm{L}^{-1}\right)$ in the equilibrium, $q_{e}$ is the adsorbed metal ion amount ( $\mathrm{mg} \mathrm{g}^{-1}$ ) at equilibrium, $X m$ represents the metal ion amount required to form a monolayer, i.e., adsorption capacity of the adsorbent $\left(\mathrm{mg} \mathrm{g}^{-1}\right)$, and $b\left(\mathrm{~L} \mathrm{mg}^{-1}\right)$ is the equilibrium constant related to free energy or net enthalpy of adsorption (boe $\mathrm{e}^{-\Delta \mathrm{H} / \mathrm{RT}}$ ). To comply with the Langmuir model of adsorption, this equation can be linearized and a plot of $\mathrm{C}_{e} / \mathrm{q}_{e}$ versus $\mathrm{C}_{e}$ should be a straight line with the slope $1 / \mathrm{Xm}$ and intercept $1 / X m b$.

\section{Freundlich Model}

The Freundlich model (40) is an empirical equation based on the adsorption on a heterogeneous surface. It does not indicate a finite sorbent uptake capacity and can only be applied to range from low to intermediate concentration. The Freundlich model equation is expressed in Equation 3.

$$
q_{e}=K_{f}\left(C_{e}\right)^{1 / n} \quad \text { Eq. } 3
$$

where, while $K_{f}\left(\mathrm{mg} \mathrm{g}^{-1}\right)$ represents the Freundlich isotherm constants relating to multilayer adsorption capacity, $1 / n\left(\mathrm{~L} \mathrm{~g}^{-1}\right)$ shows the adsorption intensity. If this equation is linearized, the plot of $\log q_{e}$ versus $\log C_{e}$ will give a straight line of slope $1 / n$ and intercept $K_{f}$.

In Equation 3, the slope $1 / n$, ranging between 0 and 1 , is a measure for the adsorption intensity or surface heterogeneity. $K_{f}$ is a constant for the system, related to the bonding energy, can be defined as adsorption or distribution coefficient, and represents the general adsorbed toxic metals capacity on the adsorbent for a unit of equilibrium concentration. The results of the Freundlich and Langmuir isotherms fitted using the data of adsorption capacity from the regression of Equation 2 and 3.

\section{FTIR Analysis of Adsorbent}

Before and after adsorption of copper on astragalus material, FTIR spectra within the range of $4000-500 \mathrm{~cm}^{-1}$ were used to determine the frequency changes in the functional groups of the adsorbent and this spectra is given in Figures 4 ( $a$ and $b$ ).

In light of this information, observed changes and shifts in FTIR bands can be indicated by the dominance of the ion exchange over the $\mathrm{Cu}$ (II) sorption on astragalus. For example, the adsorption band at approximately $3330 \mathrm{~cm}^{-1}$ is attributable to the hydroxyl groups from the polyphenols originally present in astragalus.

On the other hand, the $\mathrm{C}-\mathrm{H}$ stretching vibrations of peak characteristic can be seen at approximately $2900 \mathrm{~cm}^{-1}$, while the observed band is around $1730 \mathrm{~cm}^{-1}$ of the carboxylic acid group or its

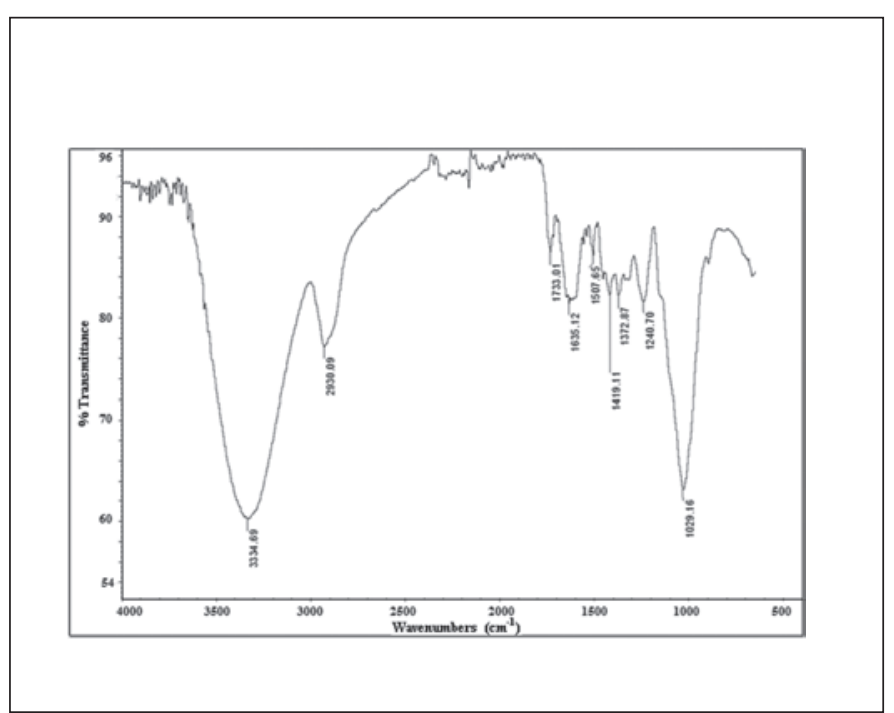

Fig. 4a. FTIR spectra of astragalus.

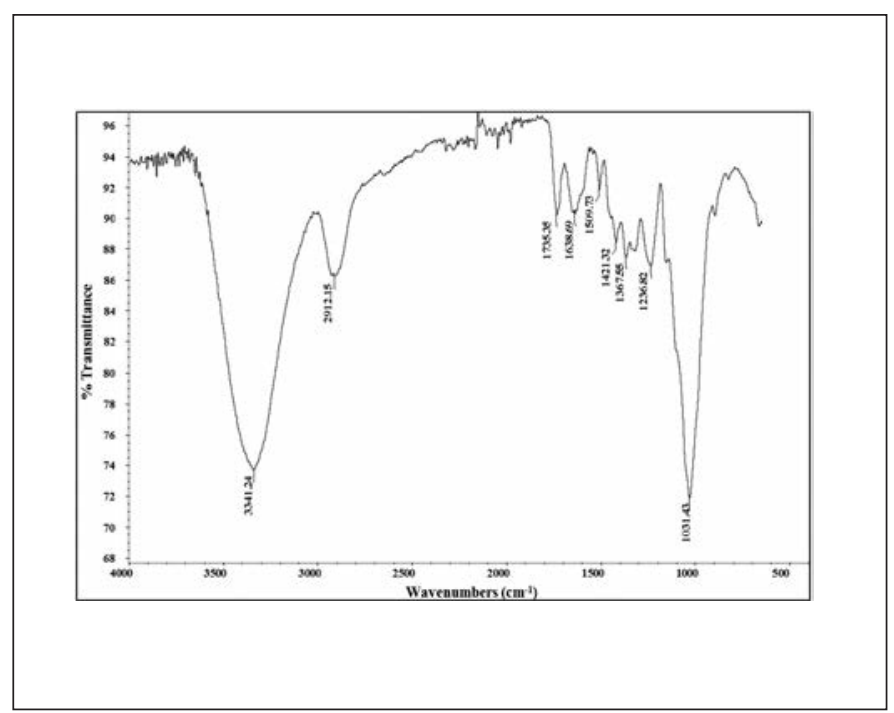

Figure 4b. FTIR spectra of Cu-loaded astragalus. 
ester. The band at 1600 symmetric and the asymmetric stretching of $\mathrm{C}=\mathrm{O}$ or $\mathrm{C}=\mathrm{C}$ aromatic vibration, in addition to the band at $1400 \mathrm{~cm}^{-1}$, is due to $\mathrm{C}-\left(\mathrm{CH}_{3}\right)_{2}$ bending. When around $1635 \mathrm{~cm}^{-1}$ it reflects the carbonyl group stretching (amide), the band around $1240 \mathrm{~cm}^{-1}$ represents stretching of OCOC acetate esters. The astragalus sample showed lower intensity peaks at $3330 \mathrm{~cm}^{-1}$, $2900 \mathrm{~cm}^{-1}$, and at $1030 \mathrm{~cm}^{-1} \mathrm{com}-$ pared with the copper loaded astragalus sample, suggesting a disruption of some of these groups during treatment. Figure 4 summarizes the shifts and changes in the FTIR bands, especially the ion exchange over the $\mathrm{Cu}$ (II) sorption on the adsorbent.

\section{Analytical Application to Real Samples}

The analytical applicability of a new and effective adsorbent was tested for the removal of $\mathrm{Cu}$ (II) from industrial wastewater and leachate samples obtained from different cities in Turkey. The developed analytical method uses the Box-Behnken experimental design in combination with the response surface modeling (RSM) and quadratic programming. An effective and eco-friendly adsorbent, the astragalus plant was applied to various real samples including industrial wastewater and some leachate samples. Under the optimum conditions, approximate $50 \mathrm{~mL}$ of real samples were filtered and adjusted to $\mathrm{pH}$ 5. In addition, $50 \mathrm{~mL}$ aliquots were spiked with $\mathrm{Cu}(\mathrm{II})$ at $\mathrm{pH} 5$. The solutions were agitated with $0.25 \mathrm{~g}$ of astragalus at a shaking speed of about $150 \mathrm{rpm}$ for 92.5 minutes. The metal ions were then eluted with $3 \mathrm{~mL}$ of $\mathrm{HNO}_{3}$ and the copper concentration determined using FAAS. The results in Table $\mathrm{V}$ clearly show the efficiency of astragalus for the removal of $\mathrm{Cu}$ (II) ions from industrial wastewater and leachate samples. The concentrations of $\mathrm{Cu}$ in the industrial waste- water and leachate samples were in the range of $9.8 \pm 0.2-15.1 \pm 0.3 \mathrm{ng}$ $\mathrm{mL}^{-1}$ and $5.9 \pm 0.2-7.5 \pm 0.2 \mathrm{ng} \mathrm{mL}^{-1}$, respectively. The accuracy of the method was verified by examining the standard reference material (SRM) SPS-SW1 Batch 119 Surface waters (Spectrapure Standards AS, Oslo, Norway). The recovery results of $99 \%$ were obtained using the standard additions method.

Kaplan Ince et al. (24) used the response surface methodology (RSM) with a quadratic model for the adsorption of cadmium from aqueous solution using eggshell as an effective adsorbent. They optimized the experimental conditions and optimal adsorption of Cd(II) was obtained at $895 \mathrm{mg} \mathrm{g}^{-1}$. Chiban et al. (41) studied a dried plant material in order to remove several heavy metals using the batch adsorption technique and obtained about $99 \%$ removal percentage for $\mathrm{Pb}$. Dong et al. (20) reported that hydroxyapatite/magnetite ( $\left.\mathrm{HAp} / \mathrm{Fe}_{3} \mathrm{O}_{4}\right)$ was produced as a novel composite adsorbent for removing $\mathrm{Pb}$ from aqueous solution and up to $99 \%$ of $\mathrm{Pb}$ (II). Gupta et al. (42) used a novel rubber tire activated carbon (RTAC) method as the adsorbent for some heavy metals including $\mathrm{Pb}$ and $\mathrm{Ni}$ from aqueous solutions. They achieved around $96 \% \mathrm{~Pb}$ and $87 \% \mathrm{Ni}$ removal by RTAC.

\section{CONCLUSION}

This study explores the astragalus plant as a new, effective, and inexpensive sorbent and an alternative to costly adsorbents for the removal of copper ions from different aqueous solutions. A batch experimental system was used to investigate the feasibility of this naturally growing plant (astragalus) as a possible adsorbent for $\mathrm{Cu}$ (II) from the aqueous medium by using the Response Surface Methodological (RSM) and Box-Behnken design approach. The results prove that this method is a very effective and time-saving technique for studying the influence of major process parameters on response factor by significantly reducing the number of experiments and hence facilitating optimum conditions. Astragalus was found suitable for $\mathrm{Cu}(\mathrm{II})$ removal from aqueous solution.

The astragalus adsorbent is low cost and eco-friendly with high sorption capacity values that are considered among the main advantages. This adsorbent has been shown to have comparable performance with commercial levels. FTIR analysis of the astragalus samples before and after copper adsorption has revealed the presence of adsorbed $\mathrm{Cu}$ because of the main functional groups that participate in metal binding such as amino, alcoholic, and ether in the adsorption process.

The Langmuir and Freundlich isotherm models were employed to describe the metal ion adsorption on astragalus. Isotherm data fit well to both the Langmuir and Freundlich models. The Langmuir model is better than the Freundlich model because generally higher $\mathrm{R}^{2}$ values were obtained for copper adsorption. The monolayer adsorption capacity $\left(\mathrm{q}_{\mathrm{e}}\right)$ obtained was 1.98 $\mathrm{mg} \mathrm{g}^{-1}$ under optimal conditions. The experimental results showed that under optimized conditions, astragalus can be used as an adsorbent for the removal of $\mathrm{Cu}$ (II) at a slightly acidic $\mathrm{pH}$ range.

\section{ACKNOWLEDGMENT}

This study was part of the project supported by Munzur University Scientific Investigations Project Unit (TUNIBAP- MFTUB012-08).

Received June 12, 2017. 


\section{REFERENCES}

1. V. Padmavathy, Bioresour. Technol. 99, 3100 (2008).

2. D. Mohan, K.P. Singh, Water Res. 36, 2304 (2002).

3. S.E. Manaham, Environmental chemistry. In: Complexation by humic substances, 6th ed.. USA: CRC Press, 1994:80_/2 (Chaper 3).

4. G.D. Matos, M.A.Z. Arruda, Process Biochem. 39, 81 (2003).

5. H.K. An, B.Y. Park, D.S. Kim, Water Res. 35, 3551 (2001).

6. A. Aklil, M. Mouflih, S. Sebti, J. Hazard. Mater. A112, 183 (2004).

7. A. Demirbas, J. Hazard. Mater. 157, 220 (2008)

8. M.J. Gonzalez-Mu noz, M.A. Rodriguez, S. Luque, J.R. Alvarez, Desalination. 200, 742 (2006).

9. H.M. Baker, A.M. Massadeh, H.A. Younes, Environ. Monit. Assess. 157, 319 (2009).

10. M.G. Khedr, Desalination Water Treat. 2, 342 (2009).

11. M. Jiang, X. Jin, X. Lu, Z. Chen, Desalination. 252, 33 (2010).

12. V. Camel, Spectrochim. Acta Part B 58, 1177 (2003).

13. P.K. Jal, S. Patel, B.K. Mishra, Talanta. 62, 1005 (2004)

14. M.E. Mahmoud, M.M. Osman, O.F. Hafez, A.H. Hegazi, E. Elmelegy, Desalination. 251, 123 (2010).

15. A. Ewecharoen, P. Thiravetyan, W. Nakbanpote, Chem. Eng. J. 137(2), 181 (2008).

16. S.B. Wang, H.W. Wu, J. Hazard. Mater. 136, 482 (2006).

17. G.K. Lim, J. Wang, S.C. Ng, C.H. Chew, L.M. Gan, Biomaterials 18, 1433 (1997).

18. I. Smiciklas, A. Onjia, S. Raicevic, Ğ. Janackovic, M. Mitric, J. Hazard. Mater. 152876 (2008).

19. T. Kaludjerovic-Radoicica, S. Raicevic, Chem. Eng. J. 160503 (2010).

20. L. Donga, Z. Zhua, Y. Qiub, J. Zhoa, J Chem Eng. 165, 827 (2010).

21. R. Ertas, N. Ozturk, Desalination Water Treat. 51, 2903 (2013).
22. M. Ince, At. Spectrosc. 35(5), 225 (2014).

23. M. Ince, O. Kaplan Ince, V. Yonten and N.M. Karaaslan, At Spectrosc. 37(3), 125 (2016).

24. O. Kaplan Ince, M. Ince, N.M. Karaaslan, and V. Yonten, Anal Lett. 49(15), 2513 (2016).

25. O. Kaplan Ince, M. Ince, V. Yonten, A. Göksu, Food Chem. 214, 637 (2017).

26. M.A.Z. Arruda, C.R.T. Tarley, G.D. Matos, Natural adsorbent materials for effluent treatment, in: J.V. Livingston (Ed.), Trends in Water Pollution Research, Nova Science Publishers, New York, 2005, pp. 137-165.

27. G.H. Pino, L.M.S. Mesquita, M.L. Torem, G.A.S. Pinto, Minerals Engineer. 19, 380 (2006).

28. S.H. Lee, C.H. Jung, H. Chung, M.Y. Lee, J.W. Yang, Proc Biochem. 33(2), 205 (1998)

29. D. Mohan, S. Chander, J. Hazard. Mater. B137, 1545 (2006).

30. K. Conrad, H.C.B. Hansen, Bioresour. Technol. 98(1), 89 (2007).

31. G. Bayramoglu, I. Tuzun, G. Celik, M. Yilmaz, M.Y. Arica, Int. J. Miner. Process. 81, 35 (2006).

32. V.K. Gupta, I. Ali, Journal of Colloid Science. 271(2), 321(2004).

33. S.E. Bailey, T.J. Olin, R.M. Bricka, D.D. Adrian, Water Res., 33, 2469 (1999).

34. N.V. Farinella, G.D. Matos, E.L. Lehmann, M.A.Z. Arruda, J. Hazard. Mater. 154, 1007 (2008).

35. M.H. Lee, S.K. Behera, H.S. Park, Int J Environ Sci Te 7, 157 (2010).

36. Z.Y. Yao, J.H. Q, L.H. Wang, J. Hazard. Mater. 174, 137 (2010).

37. E. Malkoc, Y. Nuhoglu, J. Hazard. Mater. B127, 120 (2005).

38. A. Zuorro, R. Lavecchia, Am J Appl Sci. 7 (2), 153 (2010).

39. I. Langmuir, J. Am. Chem. Soc. 40 , 1361 (1918).

40. H.M.F. Freundlich, Z. Phys. Chem. 57A, 385 (1906).

41. M. Chiban, A. Soudani, F. Sinan, S. Tahrouch, M. Persin, Clean-Soil,
Air, Water. 39(4), 376 (2011).

42. V.K. Gupta, M.R. Ganjali, A. Nayak, B. Bhushan, S. Agarwal, Chem Eng. J. 197, 330 (2012). 